\title{
Gambaran Pola Penggunaan Obat Antihipertensi Pada Pasien Rawat Inap di RSUD Panembahan Senopati
}

\author{
Anis Febri Nilansari a, ${ }^{\star}$, Nanang Munif Yasin ${ }^{\mathrm{b}, 1}$, Diah Ayu Puspandari ${ }^{\mathrm{c}, 1}$ \\ ${ }^{a}$ Program Studi Farmasi, Universitas PGRI Yogyakarta, Universitas PGRI Yogyakarta, Jawa Tengah, Indonesia \\ ' Fakultas Farmasi, Universitas Gadjah Mada, Jawa Tengah, Indonesia \\ 'Fakultas Kedokteran Kesehatan Masyarakat dan Keperawatan, Universitas Gadjah Mada, Jawa Tengah, Indonesia \\ anis@upy.ac.id** \\ ${ }^{*}$ korespondensi penulis
}

\begin{tabular}{ll}
\hline INFO ARTIKEL & ABSTRAK \\
\hline Diterima : & Hipertensi hingga kini masih menjadi masalah kesehatan di dunia. Terapi \\
04-07-2020 & yang diberikan kepada pasien hipertensi biasanya dilakukan dalam jangka \\
Disetujui : & panjang. Pengobatan hipertensi yang dilakukan sesuai dengan kondisi \\
20-07-2020 & pasien. Penelitian ini bertujuan untuk mengetahui gambaran pola \\
& penggunaan obat antihipertensi pada pasien rawat inap di RSUD \\
\hline Kata kunci: & Panembahan Senopati. Penelitian dirancang dengan metode deskriptif \\
Pola Penggunaan Obat; & crosssectional. Subyek penelitian ialah pasien hipertensi rawat inap yang \\
Antihipertensi; & memenuhi kriteria inklusi. Objek pada penelitian ini adalah rekam medis \\
Rawat Inap. & pasien rawat inap hipertensi periode bulan Oktober 20I6- Juli 20I7. \\
& Hasil penelitian menunjukkan bahwa dari 53 pasien yang memenuhi \\
kriteria inklusi, sebanyak 38 pasein (7I,8 \%) menjalani pengobatan \\
antihipertensi secara politerapi, sedangkan hanya I5 pasien (28,2 \%) \\
menjalani pengobatan monoterapi. Pengobatan monoterapi yang paling \\
banyak dipakai golongan diuretik yaitu Furosemid sebanyak 6 pasien \\
(II,3\%), sedangkan penggunakan obat politerapi yang paling banyak \\
dipakai yaitu Valsatan+ Amlodipin sebanyak I3 pasien ( 24,5\%). Secara \\
keseluruhan, golongan obat yang paling banyak digunakan adalah \\
golongan Calcium Chanel Blocker dengan jenis terbanyak adalah \\
Amlodipin, dilanjutkan golongan Diuretik yaitu Furosemid, dan golongan \\
ARB yaitu Valsartan. Penelitian ini disimpulkan bahwa penggunaan obat \\
sebagian besar politerapi dan secara umum penggunaan obat antihipertensi \\
yang dipakai terdiri dari 6 golongan obat yaitu diuretik, ACE inhibitor, \\
Angiotensin Receptor Blocker, B- blocker. \\
\hline ABSTRACT
\end{tabular}

Drug Use Patterns;

Anti-hypertension;

Inpatient.

\begin{abstract}
Hypertension is a health problem in the world. Therapy given to hypertensive patients is usually done in the long run. Hypertension treatment is carried out according to the patient's condition. This study aims to determine the pattern of the use of antihypertensive drugs in inpatients at Panembahan Senopati Hospital. The study was designed using descriptive cross sectional method. The subjects of the study were hypertensive inpatients who met the inclusion criteria. The object of this study was the medical record of hypertensive inpatients for the period October 2016-July 2017. The results showed that of 53 patients, 38 patients $(71.8 \%)$ used antihypertensive treatment by polytherapy, whereas only I5 patients $(28.2 \%)$ used monotherapy treatment. The most used monotherapy treatment of diuretics is Furosemide with 6 patients (II.3\%), while the most used polytherapy drugs are Valsatan + Amlodipin with I3 patients (24.5\%). Overall, the most used group of drugs is the Calcium Chanel Blocker with the most types, Amlodipine, followed by the Diuretic group, Furosemide, and the ARB group, Valsartan. This study concluded that the use of drugs is mostly polytherapy and in general the use of antihypertensive drugs used consists
\end{abstract}


of 6 classes of drugs namely diuretics, ACE inhibitors, Angiotensin Receptor Blockers, B-blockers.

This is an open access article under the CC-BY-SA license.

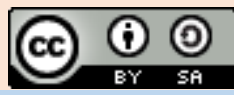

\section{Pendahuluan}

Hipertensi dikenal sebagai penyakit kardiovaskular. Hipertensi menjadi kontributor keempat kematian dini di negara maju dan ketujuh di negara berkembang. Laporan terbaru menunjukkan bahwa hampir I miliar orang dewasa (lebih dari seperempat populasi dunia) menderita hipertensi pada tahun 2000, dan hal ini diperkirakan akan meningkat menjadi I,56 miliar pada tahun 2025 .

WHO memperkirakan di dunia terdapat II\% pasien hipertensi yang tidak terdeteksi dan $50 \%$ diantaranya di negara berkembang. Profil data kesehatan Indonesia tahun 2017 menyebutkan bahwa secara nasional terjadi peningkatan prevalensi hipertensi dari 25,8 \% pada tahun 2013 menjadi 34, I \%. Peningkatan prevalensi penyakit kanker, stroke, penyakit ginjal kronis, diabetes melitus, dan hipertensi berhubungan dengan perilaku yang dijalani masyarakat Indonesia diantaranya adalah merokok, keterpaparan terhadap asap rokok, diet/pola makan tidak sehat, kurang aktivitas fisik, konsumsi minuman beralkohol, dan riwayat keluarga (keturunan). Menurut The Seventh Report of The Joint National Committee on Prevention, Detection, Evaluation and Treatment of High Blood Pressure (JNC VIII) klasifikasi tekanan darah pada orang dewasa terbagi menjadi kelompok normal, prahipertensi, hipertensi derajat I dan derajat 2.

Tujuan umum pengobatan hipertensi adalah menurunkan mortalitas dan morbiditas yang berhubungan dengan kerusakan organ target seperti gagal jantung, penyakit jantung koroner atau penyakit ginjal kronik. Target nilai tekanan darah yang direkomendasikan adalah <I40/90 mmHg untuk pasien dengan tanpa komplikasi, $<\mathrm{I30} / 80 \mathrm{mmHg}$ untuk pasien dengan diabetes dan penyakit ginjal kronis.

Terapi farmakologi yang didapatkan pasien dapat berupa obat antihipertensi tunggal atau obat antihipertensi kombinasi. Terapi kombinasi diperlukan apabila antihipertensi tunggal belum mampu mengendalikan target tekanan darah yang diinginkan.
Berdasarkan alogaritma yang disusun JNC VII, terapi paling dini adalah mengubah gaya hidup. Jika hasil yang dinginkan tak tercapai maka diperlukan terapi dengan obat. Secara umum, golongan obat antihipertensi yang dikenal yaitu, diuretik, ACE inhibitor, Angiotensin Resptor Bloker, Canal Calsium Bloker, dan Beta Bloker

Berdasarkan penelitian sebelumnya yang dilakukan oleh Khotimah dkk mengenai penggunaan obat antihipertensi menyebutkan bahwa evaluasi ketepatan obat pada penggunaan obat antihipertensi di RSUD Depok bahwa I00\% tepat pasien, dan tepat indikasi, sedangkan 55,38\% pasien tepat dosis dan tepat frekuensi pemberian. Selain itu penelitian serupa yang dilakukan oleh Eka dkk di Puskesmas Siantar Hilir Kota Pontianak bahwa secara umum pengobatan antihipertensi yang rasional yaitu sebanyak 69,56\%. Sedangkan pengobatan yang dilakukan Umul dkk bahwa terapi obat Antihipertensi yang paling banyak digunakan yaitu terapi obat kombinasi sebanyak 8 I pasien $(96,43 \%)$ dan yang menggunakan terapi tunggal hanya sebanyak 3 pasien $(3,57 \%)$.

Sehingga berdasarkan uraian diatas, maka peneliti tertarik untuk melakukan penelitian yang berjudul Gambaran Pola Penggunaan Obat Pasien Hipertensi Rawat Inap di RSUD Panembahan Senopati

\section{Metode}

Jenis penelitian ini adalah penelitian analitik non eksperimental (observasional analitik) dengan rancangan penelitian cross sectional dengan menggunakan metode pengambilan data retrospektif yang diambil dari penelusuran dokumen rekam medik di RSUD Panembahan Senopati selama periode IO bulan (Oktober 2016- Juli 2017).

\section{Bahan dan Alat}

Bahan yang digunakan dalam penelitian ini adalah catatan medik pasien dan rincian pola penggunaan obat antihipertensi di RSUD Panembahan Senopati pada periode Oktober 2016- Juli 2017.

Alat yang digunakan ialah Lembar Pengambilan Data (LPD) pasien Hipertensi yang berisi data demografi pasien (nomor rekam medik, 
jenis kelamin, dan umur) dan pola penggunaan obat (nama obat, frekuensi dan dosis, bentuk sediaan, tanggal pemberian, lama pemberian, dan diagnosis penyakit oleh dokter).

\section{Jalannya Penelitian}

Tahap Persiapan

Tahapan ini meliputi pengurusan ijin serta persiapan lembar pencatatan data pola penggunaan obat pasien hipertensi rawat inap. Surat ijin penelitian diserahkan ke kantor Badan Perencanaan Pembangunan Daerah (BAPPEDA) DIY, yang kemudian mendapat surat rekomendasi dari kantor Bappeda yang akan diteruskan ke bagian Tata Usaha RSUD Panembahan Senopati. Pada tahap persiapan, juga dilakukan pengajuan permohonan untuk mendapatkan Ethical Clearance.

\section{Tahapan Pengumpulan Data}

Pengumpulan data diambil dengan dilakukan pengambilan data dari catatan rekam medik pasien. Kasus hipertensi yang dipilih yaitu pasien hipertensi rawat inap dengan kode diagnosa I-4I7-I untuk deskripsi rawat inap hipertensi ringan dengan tingkat keparahan I (tanpa komplikasi maupun komorbiditi). Selama periode Oktober 2016 - Juli 2017 tercatat total ada 53 pasien hipertensi rawat inap kode I-4-I7-I. Semua pasien memenuhi kriteria inklusi sehingga subjek penelitian ini adalah 53 pasien dengan kategori Pulang Atas Ijin Dokter.

\section{Tahap Identifikasi Penelitian}

Data pada rekam medik yang telah didapat diklasifikasikan guna melihat pola penggunaan obat antihipertensi pada pasien hipertensi di instalasi rawat inap di RSUD Panembahan Senopati, kemudian dibandingkan dengan standar baku penelitian yang digunakan.

Data yang terkumpul akan menjalani proses pengolahan dan analisis data kemudian disajikan dalam bentuk tabel.

\section{Hasil dan Pembahasan}

Hipertensi merupakan salah satu penyakit degeneratif yang memiliki angka kejadian terbanyak di Rumah Sakit Umum Daerah Panembahan Senopati Bantul. Selama periode Oktober 2016 - Juli 2017 tercatat total ada 53 pasien hipertensi rawat inap dengan kode diagnosa I-4-I7-I.

Berdasarkan distribusi jenis kelamin pada penelitian ini, pada tabel I. menunjukkan bahwa pada penyakit hipertensi tercatat pasien jenis kelamin laki-laki $(56,6 \%)$ lebih banyak daripada pasien jenis kelamin wanita $(43,4 \%)$. Pada lakilaki resiko hipertensi akan lebih tinggi daripada wanita, laki-laki lebih dari 45 tahun dan wanita lebih dari 55 tahun akan mempunyai resiko lebih besar dibandingkan dengan remaja. American Heart Association menyatakan hingga usia 45 tahun persentase laki-laki dengan hipertensi lebih besar daripada perempuan. Pada umur 45-64 tahun jumlah pasien laki-laki dan perempuan sama, sedangkan $\geq 65$ tahun persentase perempuan lebih banyak dari laki-laki. Menurut Hospital Episode Statistics, Department of Health England tahun 2002, 52\% penderita hipertensi di Inggris adalah pria dan $48 \%$ adalah wanita.

Tabel I. Karakteristik Subyek Penelitian

\begin{tabular}{|c|c|c|}
\hline No & Variabel & $\begin{array}{c}\text { Jumlah (\%) Total } \\
\qquad(\mathrm{N}=56)\end{array}$ \\
\hline \multirow[t]{3}{*}{ I } & Jenis Kelamin & \\
\hline & Laki-laki & $30(56,6)$ \\
\hline & Perempuan & $23(43,4)$ \\
\hline \multirow[t]{4}{*}{2} & Usia & \\
\hline & $<45$ Tahun & $5(9,4)$ \\
\hline & $45-65$ Tahun & $3 \mathrm{I}(58,5)$ \\
\hline & $\geq 65$ tahun & I7 $(32, \mathrm{I})$ \\
\hline \multirow[t]{3}{*}{3} & Derajat Hipertensi & \\
\hline & Hipertensi Stadium I & $\mathrm{I} 2(22,6)$ \\
\hline & Hipertensi Stadium 2 & $4 \mathrm{I}(77,4)$ \\
\hline \multirow[t]{4}{*}{4} & Komordibiti & \\
\hline & $\begin{array}{l}\text { Hipertensi tanpa } \\
\text { komorbid }\end{array}$ & $7(13,2)$ \\
\hline & $\begin{array}{l}\text { Hipertensi dengan I } \\
\text { komorbid }\end{array}$ & $26(49)$ \\
\hline & $\begin{array}{l}\text { Hipertensi dengan }>I \\
\text { komorbid }\end{array}$ & $20(37,8)$ \\
\hline
\end{tabular}

Banyak faktor yang berperan untuk terjadinya hipertensi meliputi faktor resiko yang dapat dikendalikan dan faktor resiko yang tidak dapat dikendalikan. Faktor resiko yang dapat dikendalikan yaitu olahraga, makanan (kebiasaan makan garam), alkohol, stress, kelebihan berat badan (obesitas), kehamilan, dan penggunaan pil kontrasepsi. Sedangkan faktor resiko yang tidak dapat dikendalikan seperti keturunan, jenis kelamin, ras, dan umur.

Pemilhan kode diagnosa yang keluar yaitu kode I-4-I7-I untuk deskripsi rawat inap hipertensi ringan dengan tingkat keparahan I (tanpa komplikasi maupun komorbiditi). Namun berdasarkan hasil penelitian di tabel 2. dapat terlihat bahwa sebagaian besar yaitu $86,8 \%$ atau 46 pasien memiliki komorbiditi, sedangkan hanya $13,2 \%$ atau 7 orang pasien yang tanpa 
komorbiditi. Adanya komorbit yang diderita pasien ini dapat mempengaruhi pola penggunaan obat yang diterima pasien.

Secara umum rekomendasi obat antihipertensi menurut JNC 8 terdiri dari 5 golongan yaitu ACE Inhibitor, Angiotensin II Reseptor Bloker (ARB), Diuretik, Beta Blocker, dan Calsium Channel Bloker (CCB). Setiap golongan pada obat antihipertensi memiliki sifat farmakologi dan farmakodinamika yang berbeda. Pada Tabel 2. dapat terlihat bahwa pasien hipertensi rawat inap untuk jenis terapi tunggal paling banyak menggunakan obat yang berasal dari golongan Diuretik Tiazid. Diuretik thiazid bekerja dengan cara menurunkan resistensi pembuluh darah perifer dalam jangka panjang sementara mengurangi volume sirkulasi darah dalam jangka pendek dengan menghambat $\mathrm{Na}$ reasorbsi oleh tubulus distal. Golongan thiazid juga mempunyai efek vasodilatasi langsung pada arteriol sehingga dapat mempertahankan efek antihipertensi lebih lama.

Tabel 2. Distribusi Pola Penggunaan Obat Antihipertensi.

\begin{tabular}{|c|c|c|}
\hline Golongan & Antihipertensi & Total \\
\hline \multirow[t]{3}{*}{ Diuretik } & Furosemid & 27 \\
\hline & HCT & $\mathrm{I}$ \\
\hline & Spironolacton & 2 \\
\hline \multirow{2}{*}{$\begin{array}{l}\text { ACE } \\
\text { Inhibitor }\end{array}$} & Captopril & 17 \\
\hline & Ramipril & $\mathrm{I}$ \\
\hline \multirow{3}{*}{$\begin{array}{l}\text { Agiotensin II } \\
\text { Reseptor } \\
\text { Blocker }\end{array}$} & Telmisartan & $\mathrm{I}$ \\
\hline & Valsartan & 26 \\
\hline & Candesartan & $\mathrm{I3}$ \\
\hline \multirow{3}{*}{$\begin{array}{l}\text { Calcium } \\
\text { Chanel } \\
\text { Blobker }\end{array}$} & Amlodipin & 32 \\
\hline & Nicardipin & 4 \\
\hline & Nifedipin & 8 \\
\hline \multirow{2}{*}{ B Blocker } & Bisoprolol & II \\
\hline & Carvedilol & $\mathrm{I}$ \\
\hline \multirow{2}{*}{$\begin{array}{l}\text { Golongan } \\
\text { lainnya }\end{array}$} & Klonidin & 9 \\
\hline & Metildopa & $\mathrm{I}$ \\
\hline
\end{tabular}

Kombinasi obat yang paling banyak digunakan adalah kombinasi golongan $\mathrm{ARB}$ dengan CCB. Kombinasi obat antihipertensi dapat menurunkan tekanan darah lebih besar dengan efek samping yang minimal. Penggunaan kombinasi antihipertensi dengan dosis yang rendah lebih efektif mengurangi timbulnya efek samping dibandingkan dengan menggunakan monoterapi antihipertensi dengan dosis yang tinggi.

Penggunaan terapi dengan menggunakan kombinasi obat antihipertensi dianjurkan untuk pasien yang memiliki tekanan darah yang jauh dari target nilai tekanan darah yang seharusnya. Penambahan obat antihipertensi dari golongan yang berbeda harus dilakukan ketika penggunaan obat tunggal dengan dosis adekuat gagal mencapai tekanan darah target dan mengontrol nilai tekanan darah.

Penggunaan antihipertensi dapat dengan agen tunggal, kombinasi, ataupun penggantian. Penggantian antihipertensi adalah penggunaan obat secara tunggal lalu kombinasi dan sebaliknya, atau penggunaan kombinasi namun diganti dari golongan yang berbeda. Penggunaan agen tunggal diberikan pada keadaan hipertensi yang ringan untuk menghindari terjadinya hipotensi, sedangkan terapi kombinasi maupun penggantian diberikan pada pasien dengan hipertensi berat yang sudah tidak dapat diatasi dengan agen tunggal. Terapi kombinasi dan penggantian obat dapat menggunakan dua golongan antihipertensi atau lebih tergantung keadaan pasien.

Data rekam medis 53 pasien menunjukkan penggunaan antihipertensi dari 6 golongan obat yaitu diuretik, ACE inhibitor, Angiotensin Receptor Blocker, B- blocker, Calcium Channel Blocker, dan Antagonis Aldosteron. Tabel 2 menunjukkan golongan obat yang paling banyak digunakan adalah golongan Calcium Chanel Blocker dengan jenis terbanyak adalah Amlodipin baik pada pasien rawat inap kelas 2, dan kelas 3 dengan jumlah penggunaan obat sebanyak 32 kasus. Penelitian ini sejalan dengan penelitian yang dilakukan Sedayu dkk di RSUP DR.M Djamil Padang tahun 2013, dimana amlodipin merupakan obat antihipertensi yang paling banyak digunakan dibandingkan HCT ataupun Captopril. Amlodipin merupakan obat antihipertensi golongan antagonis kalsium yang pengunaannya sebagai monoterapi atau dikombinasikan dengan golongan obat lain seperti diuretik, ACE-inhibitor, ARA II atau beta bloker dalam penatalaksanaan hipertensi. Amlodipin juga merupakan salah satu obat antihipertensi tahap pertama sejak JNC IV dan WHO-ISH 1989 selain diuretik yangmerupakan rekomendasi JNC VIII sebagai obat antihipertensi tahap pertama. Amlodipin mempunyai mekanisme yang sama dengan antagonis kalsium golongan dihidropiridin lainnya yaitu dengan merelaksasi arteriol pembuluh darah. Amlodipin bersifat vaskuloselektif, memiliki bioavailibilitas oral yang relatif rendah, memiliki waktu paruh yang panjang, dan absorpsi yang lambat sehingga mencegah tekanan darah turun secara mendadak. 
Amlodipin juga merupakan obat yang sangat bermanfaat mengatasi hipertensi darurat karena dosis awalnya yaitu $10 \mathrm{mg}$, dapat menurunkan tekanan darah dalam waktu I0 menit.

Golongan Diuretik merupakan antihipertensi yang digunakan terbanyak kedua setelah Amlodipin. Jenis yang digunakan adalah Furosemid sebanyak 27 kasus. Selain itu golongan ARB merupakan terbanyak selanjutnya dengan penggunaan Valsartan sebanyak 26 kasus.

Berdasarkan JNC 8, tatalaksana terapi hipertensi adalah golongan diuretik tiazid, ACEI, ARB,dan CCB. Keempat golongan obat antihipertensi ini dipilih sebagai rekoendasi karena keempat golongan obat antihipertensi ini memiliki efek yang sebanding pada outcome dari penyakit kardiovaskular, sedangkan menurut Standar Pelayanan Medis Rumah Sakit Umum Daerah Panembahan Senopati menggunakan obat golongan diuretik dan ACEI. Efek diuresis dari obat diuretik dapat menyebabkan reduksi plasma, sehingga menurunkan cardiac output dan tekanan darah.

The United Kingdom Guidline, mengelompokan obat untuk hipertensi berdasarkan usia dan ras dimana direkomendasikan ACE Inhibitor sebagai lini pertama untuk pasien $<55$ tahun dan CCB serta diuretic tiazid untuk pasien dengan usia $>55$ tahun dan untuk pasien berkulit hitam.

ARB dapat digunakan sebagai terapi alternatif pada pasien yang tidak dapat mentoleransi ACEI seperti munculnya batuk kering. Studi meta-analisis menunjukkan bahwa valsartan pada dosis $160 \mathrm{mg}$ sampai $320 \mathrm{mg}$ lebih efektif menurunkan tekanan darah dibandingkan losartan dosis $100 \mathrm{mg}$. Valsartan dengan dosis yeng sebanding dengan jenis ARB yang lain juga menghasilkan efikasi yang sebanding.

Hasil penelitian jumlah obat antihipertensi pada tabel 3. terlihat bahwa lebih banyak pasien yang mendapatkan pengobatan politerapi daripada monoterapi. Pasien yang mendapatkan pengobatan politerapi yaitu 38 orang (7I,8 \%), sedangkan hanya I5 (28,2 \%) pasien yang menjalani pengobatan monoterapi. Hal tersebut serupa dengan hasil penelitian yang dilakukan oleh Luh Sonya dkk, bahwa pasien hipertensi rawat inap di RSUP Sanglah Denpasar sebagian besar mendapatkan pengobatan politerapi.

Pemilihan pengobatan politerapi dilakukan apabila perubahan gaya hidup diserati dengan pengobatan monoterapi tidak mampu menurunkan tekanan darah pasien.
Peningkatan dosis dan penambahan obat antihipertensi golongan lain dapat dilakukan apabila target tekanan darah tidak tercapai dalam waktu satu bulan pengobatan. Pemilihan antihipertensi golongan lain dipilih yang memiliki minimum efek samping dan interaksi obat. Pemilihan pengobatan politerapi yang dilakukan di RSUD Panembahan Senopati yaitu apabila pasien memiliki tekanan darah $>20 / 10$ mmHg di atas target normal atau target yang diharapkan. Hal ini sesuai dengan pedoman tata laksana yang JNC VIII bahwa menambahan obat antihipertensi golongan lain dapat diberikan apabila tekanan darah pasien $>20 / \mathrm{IO} \mathrm{mmHg}$ diatas target.

Tabel 3. Jumlah Obat Antihipertensi

\begin{tabular}{|c|c|c|}
\hline Jumlah Obat & Nama Obat & $\begin{array}{c}\text { Jumlah } \\
(\%) \\
\text { Total } \\
(\mathrm{N}=56)\end{array}$ \\
\hline \multirow{4}{*}{ Monoterapi } & Furosemid & $6(\mathrm{II}, 3)$ \\
\hline & Valsartan & $4(7,5)$ \\
\hline & Amlodipin & $4(7,5)$ \\
\hline & Captopril & $\mathrm{I}(\mathrm{I}, 9)$ \\
\hline \multirow{6}{*}{ Politerapi } & Valsartan + Amlodipin & $\begin{array}{l}\text { I3 } \\
(24,5)\end{array}$ \\
\hline & Captopril + Amlodipin & $\begin{array}{l}\text { I0 } \\
(\mathrm{I} 8,8)\end{array}$ \\
\hline & Valsartan + Furosemid & $6(\mathrm{II}, 3)$ \\
\hline & Valsartan + Bisoprolol & $6(\mathrm{II}, 3)$ \\
\hline & Captopril + Furosemid & $\mathrm{I}(\mathrm{I}, 9)$ \\
\hline & Bisoprolol + Furosemid & $2(3,7)$ \\
\hline
\end{tabular}

Terapi obat yang diberikan kepada pasien hipertensi sering ditambahkan obat lain untuk menyembuhkan atau memperbaiki kondisi pasien dari penyakit penyerta yang diderita pasien. Pada penelitian ini obat yang diresepkan di luar SPM antara lain penggunaan vitamin, analgesik non narkotik, obat saluran pencernaan, antitusif, vertigo dan obat untuk tulang yang sifatnya sebagai obat tambahan suportif.

\section{Simpulan dan Saran}

Pada penelitian ini didapatkan hasil bahwa sebagian besar pasien hipertensi rawat inap di RSUD Panembahan Senopati yaitu laki-laki dengan usia paling dominan yaitu 45-65 tahun. Pasien dengan komorbidi yaitu berjumlah 46 orang $(86,6 \%)$, sedangkan hanya 7 orang $(13,2 \%)$ pasien tanpa komorbiditi. Sebagian besar pasien menjalani pengobatan politerapi yaitu 38 orang (7I,8 \%), sedangkan hanya I5 (28,2\%) pasien 
yang menjalani pengobatan monoterapi. Secara umum penggunaan obat antihipertensi yang dipakai terdiri dari 6 golongan obat yaitu diuretik, ACE inhibitor, Angiotensin Receptor Blocker, Bblocker. Golongan obat yang paling banyak digunakan adalah golongan Calcium Chanel Blocker dengan jenis terbanyak adalah Amlodipin, dilanjutkan golongan Diuretik yaitu Furosemid sebanyak 27 orang, dan golongan ARB yaitu Valsartan sebanyak 26 kasus.

Saran dari penelitian yang dilakukan yaitu perlu dilakukan penelitian selanjutnya mengenai evaluasi kesusuaian pemberian obat antihipertensi di RSUD Panembahan Senopati untuk mengetahui ketepatan atau rasionalitas pengobatan yang dilakukan.

\section{Ucapan Terima Kasih}

Penulis mengucapkan terimakasih kepada bagian rekam medis, keuangan dan farmasi di RSUD Panembahan Senopati yang telah membantu dalam pengambilan data penelitian

\section{Daftar Pustaka}

Alonso, A., Beunza, J. J., Delgado-rodríguez, M., Martínez, J. A., \& Martínez-gonza, M. A. (2005). Low-fat dairy consumption and reduced risk of hypertension: the Seguimiento Universitat de Navarra. The American Journal of Clinical Nutrition, 972-979.

Barbara G, W., Dipiro, J. T., Schwinghammer, T. L., \& Dipiro, C. W. (2015). Pharmacotherapy Handbook Ninth Edition. In AIAA Guidance, Navigation, and Control Conference. https://doi.org/I0.25I4/6.2010-8193

Carolina G, Garcia MD, A. F. (2018). Combination therapy in the treatment of hypertension. Drugs in Context, 547-560. https://doi.org/I0.7573/dic.21253I

farida, umul, \& Cahyani, P. W. (2018). Pola Penggunaan Obat Antihipertensi Pada Pasien Hipertensi Rawat Inap Di Rsud Mardi Waluyo Blitar Bulan Juli-Desember Tahun 2016. Jurnal Wiyata Penelitian Sains Dan Kesehatan, 5(I), 29-33. Retrieved from

http://www.ojs.iik.ac.id/index.php/wiyata /article/view/I97

Go, A. S., Mozaffarian, D., Roger, V. L., Benjamin, E. J., Berry, J. D., Borden, W. B., ... Turner, M. B. (2013). Heart disease and stroke statistics-2013 update: A Report from the American Heart Association.
Circulation $127(\mathrm{I})$. https://doi.org/IO.I I6I/CIR.0b0I3e3I $828124 \mathrm{ad}$

James, P. A., Oparil, S., Carter, B. L., Cushman, W. C., Dennison-Himmelfarb, C., Handler, J., ... Ortiz, E. (20I4). 2014 Evidencebased guideline for the management of high blood pressure in adults: Report from the panel members appointed to the Eighth Joint National Committee (JNC 8). JAMA - Journal of the American Medical Association, $\quad 3 I I(5), \quad$ 507-520. https://doi.org/I0.100I/jama.2013.284 427

Joseph, A. C., Karthik, M. S., Sivasakthi, R., Venkatanarayanan, R., \& Sam Johnson Udaya Chander, J. (2016). JNC 8 versus JNC 7 - Understanding the evidences. International Journal of Pharmaceutical Sciences Review and Research, 36(I), 3843.

Kementerian Kesehatan RI. (2016). Permenkes No 762016 Tentang Pedoman Indonesian Case Base Groups (INA-CBG) Dalam Pelaksanaan Jaminan Kesehatan Nasional.

Kementerian Kesehatan RI. (2018). Profil Kesehatan Republik Indonesia Tahun 2017.

Khotimah, S. E. Y. N., \& Musnelina, L. (2016). Evaluasi Penggunaan Obat Antihipertensi Pada Pasien Hipertensi Primer Usia $\leq 45$ Tahun Di Instalasi Rawat Jalan Rumah Sakit Umum Daerah ( RSUD ) Kota Depok. Sainstech Farma ISSN: 208678I6, 9 (I), 30-34.

Lacy, C.F., Armstrong, L.L., Goldman, M.P. dan Lance, L. . (2006). Drug Information Handbook International: A Comprehensive Resource for All Clinical and Healthcare Professionals, I4th Ed, Lexi Comp Inc, Ohlo.

Nafrialdi. (2008). Antihipertensi dalam Farmakologi dan Terapi, Edisi 5, EGC,Jakarta. Indonesia.

Nixon, R. M., Müller, E., Lowy, A., \& Falvey, H. (2009). Valsartan vs, other angiotensin II receptor blockers in the treatment of hypertension: A meta-analytical approach. International Journal of Clinical Practice, 63(5), $766-775$. https://doi.org/IO.I I I I/j.I 742I24I.2009.02028.x

Olin, B. R., \& Pharm, D. (2018). Hypertension : The Silent Killer: Updated JNC-8 Guideline Recommendations. Alabama 
Pharmacy Association.

Park, J. B., Kario, K., \& Wang, J. G. (2015). Systolic hypertension: An increasing clinical challenge in Asia. Hypertension Research, $38(4)$, 227-236. https://doi.org/I0.I038/hr.20I4.I69

Pradeepa, R., \& Mohan, V. (2008). Hypertension $\&$ pre-hypertension in developing countries. Indian Journal of Medical Research, I28(6), 688-690.

Schwartz, G. L., \& Sheps, S. G. (2004). A review of the Sixth Report of the Joint National Committee on Prevention, Detection, Evaluation, and Treatment of High Blood Pressure. National Institutes of Health, I4(2), I6I-I68. https://doi.org/I0.1097/00001573I99903000-000I4

Sedayu, B., Azmi, S., \& Rahmatini, R. (2015). Karakteristik Pasien Hipertensi di Bangsal Rawat Inap SMF Penyakit Dalam RSUP DR. M. Djamil Padang Tahun 2013. Jurnal Kesehatan Andalas, 4(I), 65-69. https://doi.org/I0.25077/jka.v4iI.I92

Sonya.A.P, Bagus, J. (2019). Gambaran Pola Penggunaan Obat Antihipertensi Pada Pasien Hipertensi Di Instalasi Rawat Inap Rsup Sanglah Denpasar Tahun 2016. Jurnal Medika Udayana, 8(6), ISSN 2597-8012. Retrieved from https://ojs.unud.ac.id/index.php/eum

Untari, E. K., Agilina, A. R., Susanti, R., Studi, P., Fakultas, F., Universitas, K., \& Pontiana, T. (2018). Evaluasi Rasionalitas Penggunaan Obat Antihipertensi di Puskesmas Siantan Hilir Kota Pontianak Tahun 2015 Evaluation on Rationality of Hypertension Treatment in Puskesmas Siantan Hilir Pontianak on 2015. Pharmaceutical Sciences and Research, 5(I), 32-39. 